\title{
MENINGKATKAN PEMAHAMAN KONSEP MATEMATIKA SISWA SD MELALUI PEMBELAJARAN DENGAN PENDEKATAN PROBLEM POSING
}

\author{
Dwi Putri Wulandari ${ }^{1}$
}

\begin{abstract}
ABSTRAK
Penelitian ini bertujuan untuk mengetahui peningkatan pemahaman konsep matematika siswa yang memperoleh pembelajaran dengan pendektan problem posing, mengetahui peningkatan pemahaman konsep matematika siswa yang memperoleh pembelajaran langsung, dan mengetahui perbandingan peningkatan pemahaman konsep matematika siswa yang memperoleh pembelajaran dengan pendekatan problem posing dan pembelajaran langsung. Penelitian ini menggunakan metode eksperimen kuasi, desain penelitiannya menggunakan nonequivalent control group design dengan sampel siswa kelas IV SD di Kecamatan Cibeber Kabupaten Cianjur. Dari hasil penelitian diperoleh bahwa dengan menggunakan pendekatan problem posing pemahaman konsep matematika siswa kelas IV SD meningkat, dengan menggunakan model pembelajaran langsung pemahaman konsep matematika siswa kelas IV SD meningkat, peningkatan kemampuan pemahaman konsep matematika siswa yang memperoleh pembelajaran dengan menggunakan pendekatan problem posing lebih baik daripada siswa yang memperoleh pembelajaran dengan menggunakan model pembelajaran langsung.
\end{abstract}

Kata kunci: Problem posing, pemahaman konsep matematika

\section{A. PENDAHULUAN}

Matematika sebagai salah satu ilmu dasar, baik aspek terapannya maupun aspek penalarannya, mempunyai peranan penting dalam upaya penguasaan ilmu dan teknologi. Matematika juga dapat digunakan untuk bekal terjun dan bersosialisasi di masyarakat. Misalnya orang yang telah mempelajari matematika diharapkan bisa menyerap informasi secara lebih rasional dan berpikir secara logis dalam menghadapi situasi di masyarakat. Oleh karena itu matematika perlu diajarkan pada semua jenjang pendidikan, mulai dari SD sampai perguruan tinggi.

Tujuan pendidikan matematika secara nasional menggambarkan pentingnya pelajaran matematika mulai dari SD sampai sekolah menengah sebagaimana tercantum dalam kurikulum 2006 yaitu; (1) memahami konsep matematika, menjelaskan keterkaitan antar konsep dan mengaplikasikan konsep atau algoritma secara luwes, akurat, efisien dan tepat dalam pemecahan masalah, (2) menggunakan penalaran pada pola dan sifat, melakukan manipulasi, menyusun bukti, atau menjelaskan gagasan dan pernyataan matematika, (3) memecahkan masalah yang meliputi kemampuan memahami masalah, merancang model matematika, menyelesaikan model dan menafsirkan solusi yang diperoleh, (4)

\footnotetext{
${ }^{1}$ Mahasiswa S2 Pendidikan Dasar Universitas Pendidikan Indonesia
} 
mengkomunikasikan gagasan dengan simbol, tabel, diagram atau media lain untuk memperjelas keadaan atau masalah, (5) memiliki sikap menghargai kegunaan matematika dalam kehidupan, yaitu memiliki rasa ingin tahu, perhatian, dan minat dalam mempelajari matematika, serta sikap ulet dan percaya diri dalam pemecahan masalah (Depdiknas, 2006).

Untuk mencapai tujuan tersebut perlu proses pembelajaran yang efektif dan efisien. Proses pembelajaran merupakan sebuah kegiatan di mana terjadi penyampaian materi pembelajaran dari seorang guru kepada para siswa yang dimilikinya. Interaksi antara guru dan siswa merupakan cara utama untuk kelangsungan proses pembelajaran. Keberhasilan guru dalam proses pembelajaran dapat dilihat pada proses akhir pembelajaran yang mengarah pada hasil belajar siswa.

Pembelajaran matematika di SD merupakan dasar bagi penerapan konsep matematika pada jenjang selanjutnya. Oleh karena itu, seharusnya dalam pelaksanaan pembelajaran matematika di SD mampu menata dan meletakkan dasar pengetahuan matematika siswa yang dapat membantu memperjelas penyelesaian masalah dalam kehidupan sehari-hari dan kemampuan berkomunikasi dengan bilangan dan simbol-simbol, serta lebih mengembangkan sikap logis, kritis, cermat, disiplin, terbuka, optimis, dan menghargai matematika.

Salah satu masalah pokok dalam pembelajaran matematika SD di Indonesia dewasa ini adalah masih rendahnya pemahaman konsep matematika. Agar pemahaman konsep siswa meningkat perlu adanya perbaikan dalam proses pembelajaran. Menurut Ruseffendi (2006, hlm. 328), selama ini matematika yang dipelajari siswa di sekolah diperoleh melalui pemberitahuan (dengan cara ceramah/eskpositori), bacaan, meniru, melihat, mangamati dan sebagainya, bukan diperoleh melalui penemuan. Hal ini dapat menyebabkan terjadinya berbagai kesalahan siswa dalam memahami konsep matematika. Salah satu kesalahan siswa adalah siswa lupa (keliru) menggunakan rumus yang akan digunakan dalam menyelesaikan masalah. Lebih lanjut kesalahan disebabkan karena kecenderungan siswa yang hanya menghapal rumus, bukan memahami bagaimana rumus itu terjadi, sehingga apa yang dipelajarinya mudah terlupakan. Hal ini dapat terjadi karena pembelajaran tidak mendorong siswa untuk memahami konsep matematika.

Pemahaman konsep merupakan kecakapan yang paling dasar dalam matematika. Kilpatrick (dalam Noperlinda, 2010, hlm. 4) menyatakan kecakapan ini sangat mempengaruhi kecakapan-kecakapan matematika yang lain. Dengan kata lain kemampuan pemahaman konsep matematika akan mempengaruhi kualitas belajar siswa dan pada akhirnya mempengaruhi prestasi belajar matematika siswa secara keseluruhan. Seorang siswa tidak akan mampu menyelesaikan suatu permasalahan sesuai dengan prosedurnya jika ia tidak memiliki pemahaman konsep yang baik. Begitu juga halnya dalam mengembangkan komponen kompetensi strategik dan penalaran adaptifnya. Jika tingkat pemahaman konsepnya masih rendah, siswa tidak akan mampu mengembangkan komponen-komponen tersebut. Oleh karena itu menumbuhkan dan mengembangkan pemahaman konsep sangat penting bagi siswa, terutama bagi siswa SD.

Mengingat peranan pemahaman konsep matematika sangat penting dalam proses peningkatan kemampuan berpikir matematika, maka upaya peningkatan 
pemahaman konsep matematika pada siswa SD memerlukan perhatian yang serius. Upaya ini menjadi sangat penting mengingat beberapa penelitian yang menerangkan bahwa hasil pembelajaran matematika di sekolah belum menunjukkan hasil yang memuaskan (Djazuli, 1999). Rendahnya hasil yang dicapai dalam evaluasi nasional matematika ini, menunjukkan bahwa kualitas pemahaman siswa dalam matematika masih relatif rendah. Pemahaman dalam matematika sudah sejak lama menjadi isu penting. Tidak sedikit hasil riset dan pengkajian dalam pembelajaran matematika berkonsentrasi dan berupaya menggapai pemahaman, namun sudah diyakini oleh kebanyakan bahwa untuk mencapai pemahaman dan pemaknaan matematika tidak segampang membalik telapak tangan.

Selain itu berdasarkan penelitian Syafrianto (2014) menyatakan bahwa kemampuan pemahaman konsep matematis siswa SD masih berada pada kualifikasi kurang. Dan sebagian besar guru banyak yang mengeluhkan rendahnya kemampuan siswa dalam memahami materi yang diajarkan. Pada mulanya siswa menyenangi pelajaran matematika, hal ini terlihat ketika siswa masih berada di kelas rendah dan mereka menganggap matematika itu mudah, namun semakin lama mereka merasa semakin tidak menyenangi bahkan takut karena merasa kesulitan dan tidak memahami cara menyelesaikan tugas-tugas. Dari fakta tersebut peneliti merasa perlu untuk mengembangkan kemampuan pemahaman konsep matematika bagi siswa SD.

Kondisi seperti ini perlu pengkajian lebih lanjut berkaitan dengan penggunaan pendekatan pembelajaran. Salah satu cara yang dapat dilakukan adalah menekankan pengembangan kemampuan siswa dalam membentuk soal/ membuat pertanyaan (problem posing). Problem posing merupakan salah satu inti kegiatan matematika sehingga merupakan komponen yang sangat penting dalam kurikulum matematika yang dinyatakan oleh English (1998, hlm.83): "It is well recognized that problem posing is an important component of the mathematics curriculum and, indeed, lies at the heart of mathematical activity."

Rekomendasi tersebut menunjukkan bahwa problem posing merupakan suatu aktivitas dalam pembelajaran matematika yang dapat mengembangkan kemampuan matematika siswa, karena dalam pembelajaran problem posing, siswa baik secara individu maupun kelompok akan mendapat pengalaman langsung untuk mengajukan masalahnya sendiri.

Dalam kegiatan pembelajaran problem posing, siswa dibimbing untuk merumuskan atau mengajukan masalah atau pertanyaan berdasarkan situasi yang diberikan oleh guru. Dalam merumuskan suatu masalah, siswa harus berpikir dan bernalar, menciptakan dan mengkomunikasikan ide-ide matematis, bekerja sama dan beragumen dalam merumuskan dan menyelesaikan soal dengan temannya, menggunakan informasi yang tersedia untuk menyelesaikan masalah serta memikirkan cara yang paling tepat dan masuk akal untuk menyelesaikan masalah yang telah dirumuskan.

Selain itu, problem posing memberikan kesempatan seluas-luasnya kepada siswa untuk merekonstruksi pikirannya dalam membentuk soal atau membuat pertanyaan. Kegiatan ini memungkinkan siswa untuk melakukan kegiatan yang lebih bermakna sesuai dengan schemata yang dimiliki siswa (Hudoyo, 1988, hlm. $5)$. 
Belajar dengan problem posing mengandung arti bahwa siswa diajar untuk membuat masalah sendiri sesuai dengan situasi yang ada. Persoalan seperti ini tidak mudah bagi siswa karena dalam membentuk masalah siswa harus memikirkan, menceritakan ide-idenya dalam bentuk masalah sampai kepada taraf pengungkapan melalui kegiatan diskusi secara klasikal. Pengungkapan atau komentar siswa setiap proses pembelajaran terhadap masalah yang dirumuskan sendiri dapat meningkatkan hasil belajar dan semakin terlatih keterampilan berpikir untuk memahami konsep yang dipelajari.

Berdasarkan uraian di atas, maka penulis tertarik untuk melaksanakan penelitian dengan judul "Meningkatkan Pemahaman Konsep Matematika Siswa SD Melalui Pembelajaran Dengan Pendekatan Problem Posing”.

\section{B. METODE PENELITIAN}

Penelitian ini adalah kuasi eksperimen, menggunakan dua kelompok subjek penelitian yaitu kelompok eksperimen yang diberikan pembelajaran dengan menggunakan pendekatan problem posing dan kelompok kontrol yang diberikan pembelajaran dengan model pembelajaran langsung. Kedua kelompok ini akan diberikan pretes dan postes dengan menggunakan instrumen yang sama. Desain penelitian yang digunakan dalam penelitian ini adalah pretes-postes Nonequivalent control group design.

Populasi dalam penelitian ini adalah seluruh siswa kelas IV SD di Kecamatan Cibeber, Kabupaten Cianjur tahun ajaran 2014/2015. Sampel dalam penelitian ini adalah seluruh siswa kelas IV dari 2 sekolah di Kecamatan Cibeber yang diambil secara acak. Selanjutnya dari 2 sekolah ini ditetapkan seluruh siswa kelas IV dari satu sekolah sebagai kelompok eksperimen, sedangkan satu sekolah yang lain sebagai kelompok kontrol. Kelompok eksperimen adalah kelompok siswa yang memperoleh pembelajaran dengan pendekatan problem posing, sedangkan kelompok kontrol adalah kelompok siswa yang memperoleh model pembelajaran langsung .

Data dalam penelitian ini menggunakan instrumen tes (pretes-postes). Instrumen tes terdiri dari seperangkat soal uraian untuk mengukur kemampuan pemahaman konsep matematika. Tes pemahaman konsep matematika digunakan untuk mengukur kemampuan penguasaan konsep matematika siswa secara menyeluruh terhadap materi yang disampaikan setelah kedua kelompok mendapat pembelajaran.

Data yang sudah dikumpulkan, selanjutnya diolah dan dianalisis. Data dianalisis secara kuantitatif dengan menggunakan uji statistik adalah kemampuan pemahaman konsep matematika. Skor kemampuan pemahaman konsep dalam bentuk interval, maka dapat langsung dihitung gain ternormalisasi, uji prasyarat hipotesis dan uji hipotesis. Pengolahan data dilakukan dengan bantuan software SPSS 16 dan Microsoft Excel 2007.

Data-data kuantitatif yang diperoleh adalah dalam bentuk data pretes, postes, dan N-gain. Data hasil pretes, postes dan n-gain diolah dengan menggunakan bantuan software SPSS 16. Berikut ini tahapan pengolahan data kuantitatif tes kemampuan pemahaman konsep matematika; a) Uji Normalisasi, dilakukan untuk menentukan apakah data yang didapat berdistribusi normal atau tidak. Uji normalitas ini dilakukan terhadap data pretes dan data postes dari dua kelompok siswa (kelompok eksperimen dan kelompok kontrol). Perhitungannya 
dengan menggunakan SPSS for windows 16.0 melalui uji Shapiro-Wilk. Dengan kriteria pengujian adalah terima $\mathrm{H}_{0}$ jika $\mathrm{Sig} . \geq 0,05$ dan tolak $\mathrm{H}_{0}$ apabila Sig. $<0,05$ dengan taraf signifikansi $(\alpha=0,05)$. Jika kedua data berasal dari distribusi yang normal, maka dilanjutkan dengan uji homogenitas. Sedangkan jika hasil pengujian menunjukkan bahwa sebaran dari salah satu atau semua data tidak berdistribusi normal, maka pengujian hipotesis dilanjutkan dengan statistika non parametrik, yaitu dengan menggunakan uji Mann-Whitney. b) Uji homogenitas, bertujuan untuk mengetahui kedua kelompok sampel mempunyai varians yang homogen atau tidak. Kriteria pengujiannya adalah terima $\mathrm{H}_{0}$ apabila Sig. Based on Mean > taraf signifikansi $(\alpha=0,05)$. Jika data berdistribusi normal dan homogen, maka uji beda yang digunakan adalah uji $\mathrm{t}$, dengan kriteria pengujian adalah tolak $\mathrm{H}_{0}$ jika $\mathrm{t}$ hitung $>\mathrm{t}_{\text {tabel}}$, dengan kata lain diterima. Jika data berdistribusi normal tetapi tidak homogen maka digunakan uji t', sedangkan jika datanya tidak memenuhi kriteria normal, maka uji statistik yang digunakan adalah dengan pengujian nonparametrik, dan c) Uji perbedaan dua rata-rata, dilakukan pada data pretes dan data postes atau data n-gain. Jika hasil data pretes menunjukkan bahwa kedua kelompok sama, maka untuk melihat bagaimana pencapaian kemampuan pemahaman konsep dilakukan uji perbedaan dua rata-rata terhadap data postes, sedangkan untuk melihat bagaimana peningkatan kemampuan pemahaman konsep matematika siswa maka dilakukan uji perbedaan dua rata-rata terhadap data $n$ gain.

\section{HASIL DAN PEMBAHASAN}

Berikut ini adalah gambaran secara singkat data hasil pretes, postes dan Ngain pada kelompok eksperimen dan kelompok kontrol disajikan sebagai berikut.

Statistik Deskriptif Hasil Tes Kemampuan Pemahaman Konsep Matematika

\begin{tabular}{|c|c|c|c|c|c|c|}
\hline \multirow{2}{*}{ Data Statistik } & \multicolumn{3}{|c|}{ Kelompok Eksperimen } & \multicolumn{3}{c|}{ Kelompok Kontrol } \\
\cline { 2 - 7 } & Pretes & Postes & $N$-gain & Pretes & Postes & $N$-gain \\
\hline Banyak data & 17 & 17 & 17 & 16 & 16 & 16 \\
\hline Skor Maks Ideal & 36 & 36 & 1 & 36 & 36 & 1 \\
\hline Skor minimum & 3 & 17 & 0,18 & 3 & 9 & 0,04 \\
\hline Skor maksimum & 14 & 32 & 0,85 & 15 & 24 & 0,52 \\
\hline Rata-rata skor & 7,47 & 22,35 & 0,51 & 9,25 & 15 & 0,21 \\
\hline Standar Deviasi & 3,22 & 5,06 & 0,20 & 4,17 & 4,69 & 0,13 \\
\hline
\end{tabular}

Peningkatan pemahaman konsep matematika yang memperoleh pembelajaran dengan pendekatan problem posing mengalami peningkatan berdasarkan analisis deskriptif terhadap data pretes dan postes. Hal ini ditunjukkan dengan peningkatan skor rata-rata siswa sebelum dan sesudah proses pembelajaran. Pada kelompok eksperimen skor rata-rata siswa meningkat dari 7,47 menjadi 22,35.

Peningkatan kemampuan pemahaman konsep matematika pada kelompok kontrol juga mengalami peningkatan. Hal ini ditunjukkan dengan peningkatan dengan peningkatan skor rata-rata siswa sebelum dan sesudah proses pembelajaran. Dan pada kelompok kontrol skor rata-rata siswa meningkat dari 9,25 menjadi 15 . 


\begin{tabular}{|c|c|c|c|}
\hline \multirow{2}{*}{ Kelompok } & $\begin{array}{c}\boldsymbol{N} \text {-Gain } \\
(<\mathbf{g}>)\end{array}$ & Kategori & $\begin{array}{c}\text { Banyak Siswa } \\
(\text { dalam \%) }\end{array}$ \\
\hline \multirow{3}{*}{ Eksperimen } & $\langle g\rangle>0,70$ & Tinggi & 29,4 \\
\cline { 2 - 4 } & $0,30<\langle g\rangle \leq 0,70$ & Sedang & 58,8 \\
\cline { 2 - 4 } & $\langle g\rangle \leq 0,30$ & Rendah & 11,8 \\
\hline \multirow{2}{*}{ Kontrol } & $\langle g\rangle>0,70$ & Tinggi & 0 \\
\cline { 2 - 4 } & $0,30<\langle g\rangle \leq 0,70$ & Sedang & 25 \\
\cline { 2 - 4 } & $\langle g\rangle \leq 0,30$ & Rendah & 75 \\
\hline
\end{tabular}

Siswa pada kelompok eksperimen dan siswa pada kelompok kontrol mengalami peningkatan kemampuan pemahaman konsep matematika dengan kualitas yang berbeda. Kualitas peningkatan pemahaman konsep matematika siswa dapat dilihat dari data $N$-gain masing-masing kelompok. Berdasarkan analisis data deskriptif pada bagian sebelumnya, diperoleh bahwa peningkatan kemampuan pemahaman konsep matematika pada kelompok eksperimen berada pada kategori sedang dengan rata-rata 0,51. Sedangkan peningkatan kemampuan pemahaman konsep matematika pada kelompok kontrol berada pada kategori rendah dengan rata-rata 0,21. Pada kelompok eksperimen 29,4\% siswa memiliki kualitas peningkatan pemahaman konsep matematika dengan kategori tinggi, $58,8 \%$ siswa memiliki kualitas peningkatan dengan kategori sedang, dan 11,8\% siswa memiliki kualitas peningkatan dengan kategori rendah. Berdasarkan hal tersebut, terlihat bahwa sebagian kecil siswa yang memiliki kualitas peningkatan dengan kategori rendah, dan sebagian besar memiliki kualitas peningkatan dengan kategori sedang. Pada kelompok kontrol 0\% siswa memiliki kualitas peningkatan pemahaman konsep matematika dengan kategori tinggi, 25\% siswa memiliki kualitas peningkatan dengan kategori sedang, dan 75\% siswa memiliki kualitas peningkatan dengan kategori rendah. Berdasarkan hal tersebut, terlihat bahwa sebagian kecil siswa yang memiliki kualitas peningkatan dengan kategori tinggi, dan sebagian besar memiliki kualitas peningkatan dengan kategori rendah.

Dengan demikian dapat disimpulkan bahwa pembelajaran dengan pendekatan problem posing memberikan kontribusi yang lebih baik dalam perkembangan kemampuan pemahaman konsep matematika. Kesimpulan tersebut perlu dibuktikan dengan uji statistik inferensial yang relevan. Dalam penelitian ini peneliti melakukan penghitungan dengan menggunakan bantuan program software SPSS 16 dan Microsoft Office Excel 2007.

Analisis data yang pertama sebelum menguji hipotesis maka perlu menganalisis hasil pretes kemampuan pemahaman konsep untuk melakukan uji kesamaan dua rata-rata agar mengetahui kemampuan awal pemahaman konsep siswa. Adapun hasil analisis data pretes kemampuan nilai signifikansi skor pretes pada kelompok eksperimen sebesar 0,249 sedangkan untuk kelompok kontrol sebesar 0,165. Nilai ini lebih besar dari taraf signifikansi $\propto=0,05$. Dengan memperhatikan kriteria pengujian, skor pretes di kelompok eksperimen dan kelompok kontrol berdistribusi normal. Selanjutnya dilakukan uji homogenitas, didapatkan bahwa levene's tes (sig) sebesar 0,098 lebih besar dari 0,05 maka data pretes memiliki varians homogen. Maka tahap selanjutnya uji kesamaan dua ratarata dengan menggunakan uji $\mathrm{t}$, didapatkan nilai signifikansi 2-tailed uji $\mathrm{t}$ Independent Sample Test data pretes kemampuan awal pemahaman konsep siswa 
adalah 0,179 lebih besar dari $\propto=0,05$ maka $\mathrm{H}_{0}$ diterima, dengan perkataan lain bahwa tidak terdapat perbedaan rata-rata kemampuan awal pemahaman konsep matematika antara siswa yang memperoleh pembelajaran dengan pendekatan problem posing dengan siswa yang memperoleh pembelajaran langsung secara signifikan.

Karena tidak terdapat perbedaan rata-rata kemampuan awal pemahaman konsep siswa, maka analisis selanjutnya dilihat dari data postes dari kelompok eksperimen dan kelompok kontrol. Untuk menentukan apakah akan diuji secara parametrik atau nonparametrik maka harus melakukan uji normalitas, adapun hasil uji normalitas data postes didapatkan nilai signifikansi skor postes pada kelompok eksperimen sebesar 0,220 dan kelompok kontrol 0,148. Nilai signifikansi kedua skor postes tersebut lebih besar dari $\propto=0,05$ sehingga dengan memperhatikan kriteria pengujian normalitas, maka $\mathrm{H}_{0}$ diterima yang menyatakan bahwa data postes kemampuan pemahaman konsep matematika siswa pada kelompok eksperimen dan kelompok kontrol berdistribusi normal, maka tahap selanjutnya adalah uji homogenitas.

Dari hasil uji homogenitas diperoleh nilai signifikansi Levene's test untuk data postes kemampuan pemahaman konsep matematika siswa adalah 0,696. Nilai ini lebih besar dari nilai $\propto=0,05$. Dengan demikian, berdasarkan kriteria pengujian homogenitas di atas, maka $\mathrm{H}_{0}$ diterima. Hal ini berarti data postes kemampuan pemahaman konsep matematika siswa dari kedua kelompok homogen. Dengan demikian, asumsi statistik untuk melakukan uji perbedaan dua rata-rata secara parametrik telah terpenuhi. Selanjutnya untuk mengetahui signifikansi perbedaan kemampuan pemahaman konsep matematika pada kedua kelompok dilakukan menggunakan uji t Independent Sample Test.

Uji perbedaan rata-rata ini menggunakan kriteria pengujian hipotesis satu pihak (1-tailed). Dari hasil uji t diperoleh sig (2-tailed) sebesar 0,000. Karena uji yang digunakan adalah uji satu pihak maka digunakan setengah dari nilai signifikannya yaitu $\frac{0,000}{2}$ hasilnya lebih kecil dari $\alpha=0,05$. Dengan memperhatikan kriteria pengujian maka $\mathrm{H}_{0}$ ditolak. Dengan kata lain kemampuan pemahaman konsep matematika akhir siswa yang memperoleh pembelajaran dengan pendekatan pembelajaran problem posing lebih baik daipada siswa yang memperoleh pembelajaran dengan model pembelajaran langsung secara signifikan. Selanjutnya untuk mengetahui apakah peningkatan pemahaman konsep matematika siswa yang memperoleh pembelajaran dengan pendekatan problem posing lebih baik daripada siswa yang memperoleh pembelajaran langsung, maka dilakukan analisis statistik deskriptif $\mathrm{N}$-gain.

\section{PEMBAHASAN}

Berdasarkan uji statistik data kemampuan pemahaman konsep matematika siswa dapat disimpulkan bahwa pencapaian kemampuan pemahaman konsep matematika siswa kelompok eksperimen lebih baik daripada siswa kelompok kontrol, sedangkan pada peningkatan kemampuan pemahaman konsep matematika secara data desktiptif diperoleh rata-rata n-gain kelompok eksperimen lebih tinggi daripada kelompok kontrol.

Oleh karena itu pembelajaran dengan pendekatan problem posing menunjukkan peran yang cukup berarti dalam meningkatkan kemampuan 
pemahaman konsep matematika siswa. Beberapa hal atau alasan yang menyebabkan kemampuan pemahaman konsep kelompok eksperimen relatif lebih baik dibandingkan dengan kelompok kontrol, diantaranya yaitu sesuai dengan tahapan dalam pembelajaran dengan pendekatan problem posing yaitu accepting (menerima) dan challenging (menantang). Tahap menerima adalah suatu kegiatan ketika siswa menerima situasi-situasi yang diberikan guru atau situasi-situasi yang sudah ditentukan, dan tahap menantang adalah suatu kegiatan ketika siswa menantang situasi tersebut dengan membuat pertanyaan (Brown dan Walter, 1990, hlm. 15). Selain itu dalam kelompok eksperimen diberikan Lembar Kerja Siswa (LKS) dan lembar problem posing. LKS ini berfungsi untuk memfasilitasi siswa membangun pengetahuan dan pemahamannya berdasarkan pengalaman belajar mereka sendiri.

Belajar dengan problem posing mengandung arti bahwa siswa diajar untuk membuat masalah sendiri sesuai dengan situasi yang ada. Persoalan seperti ini tidak mudah bagi siswa karena dalam membentuk masalah siswa harus memikirkan, menceritakan ide-idenya dalam bentuk masalah sampai kepada taraf pengungkapan melalui kegiatan diskusi secara klasikal. Pengungkapan atau komentar siswa setiap proses pembelajaran terhadap masalah yang dirumuskan sendiri dapat meningkatkan hasil belajar dan semakin terlatih keterampilan berpikir untuk memahami konsep yang dipelajari.

Sutawidjaja dan Dahlan (dalam Trisnawati, 2014, hlm. 20) menyatakan bahwa problem posing memuat lebih dari suatu teknik pembelajaran berpikir kritis; ini merupakan filosofis, suatu cara berpikir tentang siswa dan kemampuan mereka untuk berpikir dengan kritis dan merefleksi secara analitis kehidupan mereka. Auerbach (Trisnawati, 2014, hlm. 20) menetapkan lima langkah dalam mengimplementasikan pendekatan problem posing, yaitu gambarkan situasi (describethe content), rumuskan masalah (define the problem), pikirkan dan rasakan adanya masalah (personalize the problem), diskusikan masalah (discuss the problem), dan diskusikan beberapa alternatif pemecahan (discuss alternatives to the problem).

Suryanto (1998, hlm. 3) menyatakan bahwa problem posing merupakan salah satu alternatif pembelajaran yang dapat mengembangkan kemampuan berpikir kreatif dan bernalar matematis. Ada tujuh sistem kerja berpikir matematis atau pola pikir matematis, yaitu; (1) memahami, (2) keluar dari kemacetan, (3) mengidentifikasi kekeliruan, (4) meminimumkan pekerjaan berhitung dan menulis, (5) tekun, (6) siap mencari jalan lain, dan (7) merumuskan soal/problem posing. Hasil penelitian ini menunjukkan bahwa pendekatan problem posing tidak hanya mampu meningkatkan kemampuan matematika secara umun, dan dapat meningkatkan kemampuan berpikir kreatif dan bernalar matematis, tetapi juga dapat meningkatkan pemahaman konsep matematika siswa.

Berdasarkan hasil penelitian, maka diperoleh kesimpulan yaitu dengan menggunakan pendekatan pembelajaran problem posing pemahaman konsep matematika siswa kelas IV SD meningkat, dengan menggunakan model pembelajaran langsung (direct instruction) pemahaman konsep matematika siswa kelas IV meningkat, dan peningkatan kemampuan pemahaman konsep matematika siswa yang memperoleh pembelajaran dengan menggunakan pendekatan problem posing lebih baik daripada siswa yang memperoleh pembelajaran dengan menggunakan model pembelajaran langsung. 


\section{DAFTAR PUSTAKA}

Brown, S.I. dan walter, M.I. (1990). The art of problem posing (second edition). New Jersey: Lawrence Erlbaum Associates Publishers

Depdiknas. (2003). Pedoman khusus pengembangan sistem penilaian berbasis kompetensi SMP. Jakarta: Depdiknas.

Hudoyo, H. (1988). Mengajar belajar matematika. Jakarta: Depdikbud.

Noperlinda. (2010). Penerapan pembelajaran kontekstual untuk meningkatkan pemahaman konsep (conceptual understanding) dan disposisi matematik (mathematical disposition) siswa sekolah dasar. (Tesis). Sekolah Pascasarjana, Universitas Pendidikan Indonesia, Bandung.

Ruseffendi, E.T. (2005). Dasar-dasar penelitian pendidikan dan bidang noneksakta lainnya. Bandung: Tarsito.

Suryanto. (1998) Pembentukan soal dalam pembelajaran matematika. Makalah pada Seminar Nasional Upaya-upaya Meningkatkan Peran Pendidikan Matematika dalam Menghadapi Era Globalisasi, Malang.

Syafrianto. (2014). Peningkatan kemampuan pemahaman dan penalaran matematika serta kebiasaan berfikir (habits of mind) siswa SMP melalui model pembelajaran kooperatif tipe make a match. (Tesis). Sekolah Pascasarjana, Universitas Pendidikan Indonesia, Bandung. 